
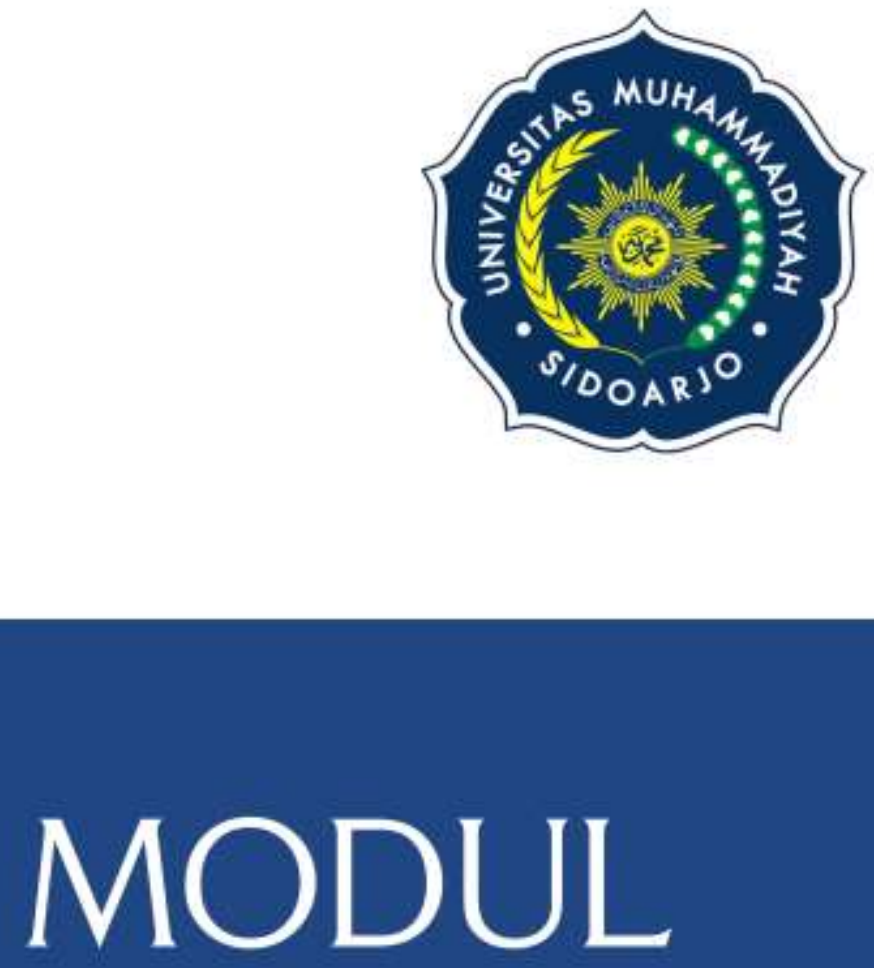

\title{
Penyelesaian Kredit Bermasalah dan Pencatatan Akuntansinya
}

\author{
Penulis: \\ Sarwenda Biduri, SE., MSA \\ Eny Maryanti, SE., M.A \\ Alshaf Pebrianggara, SE., MM
}

Fakultas Bisnis Hukum dan Ilmu Sosial Universitas Muhammadiyah Sidoarjo 
Buku Modul

Penyelesaian Kredit Bermasalah dan Pencatatan Akuntansinya

Penulis :

Sarwenda Biduri, SE., MSA

Eny Maryanti, SE., M.A

Alshaf Pebrianggara, SE., MM

ISBN :

978-623-6833-59-9

Editor :

Dr. Sigit Hermawan, SE.,M.Si

Wiwit Hariyanto, SE.,M.Si

Copy Editor :

Mahardika Darmawan Kusuma Wardana, M.Pd.

Design Sampul dan Tata Letak :

Endra Wahyu Ningdiyah, S.Ak

Penerbit :

UMSIDA Press

\section{Redaksi :}

Universitas Muhammadiyah Sidoarjo

Jl. Mojopahit No 666B

Sidoarjo, Jawa TImur

Cetakan pertama, 2020

(C) Hak cipta dilindungi undang-undang

Dilarang memperbanyak karya tulis ini dengan suatu apapun

tanpa ijin tertulis dari penerbit. 


\section{KATA PENGANTAR}

Puji syukur kepada Tuhan Yang Maha Esa, sehingga Modul "Penyelesaian Kredit Bermasalah dan Pencatatan Akuntansinya" ini dapat disusun dengan baik meskipun perlu penyempurnaan lebih lanjut. Dengan selesainya penulisan buku modul ini penulis mengucapkan terima kasih kepada semua pihak yang telah memberikan bahan-bahan tulisan baik langsung maupun tidak langsung.

Modul Penyelesaian Kredit Bermasalah dan Pencatatan Akuntansinya ini seluruhnya terdiri dari tiga bagian; bagian pertama yaitu pendahuluan yang memberikan gambaran umum mengenai kondisi perbankan dengan adanya kredit macet. Bagian kedua menguraikan pembahasan teori mengenai kredit macet dan pada bagian ketiga berisi mengenai soal latihan dan lembar kerja.

Penulis berharap dengan memaparkan berbagai aspek yang berhubungan dengan Akuntansi Badan Usaha Milik Desa atau lebih tepatnya Badan Kredit Desa (BKD), semoga dapat memberikan banyak manfaat. Khususnya yaitu kepada mahasiswa akuntansi Universitas Muhammadiyah Sidoarjo.

Akhir kata, kritik dan saran sangat diharapkan untuk penyempurnaan buku modul ini. Harapan kami semoga buku modul ini dapat digunakan sebagai tambahan informasi dan bermanfaat bagi aktivitas pembelajaran mata kuliah Akuntansi Sektor Publik di Program Studi Akuntansi, Fakultas Bisnia Hukum dan Ilmu Sosial, Universitas Muhammadiyah Sidoarjo.

Sidoarjo, 24 Desember 2020

Penulis 


\section{DAFTAR ISI}

\begin{tabular}{|c|c|}
\hline 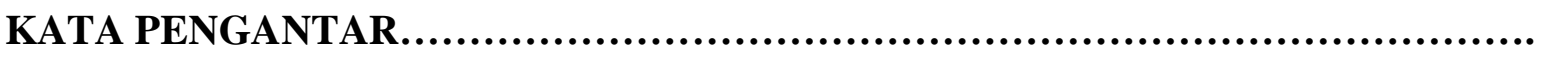 & ii \\
\hline 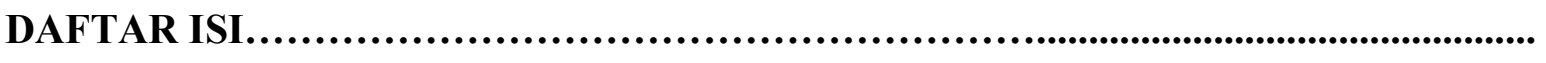 & iii \\
\hline 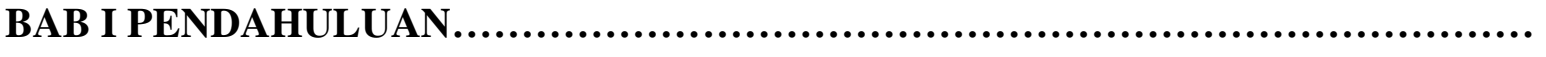 & 1 \\
\hline BAB II PEMBAHASAN TEORI........................................................ & 3 \\
\hline KREDIT PERBANKAN.......... & 3 \\
\hline PRINSIP 5C ............. & 4 \\
\hline KREDIT BERMASALAH............. & 5 \\
\hline KEBIJAKAN MENGATASI KREDIT MACET $\ldots \ldots \ldots \ldots \ldots \ldots \ldots \ldots \ldots \ldots \ldots \ldots \ldots \ldots$ & 6 \\
\hline BAB III SOAL LATIHAN DAN LEMBAR KERJA $\ldots \ldots \ldots \ldots \ldots \ldots \ldots \ldots \ldots \ldots \ldots \ldots \ldots \ldots$ & 8 \\
\hline LATIHAN SOAL $1 \ldots .$. & 8 \\
\hline LEMBAR KERJA $1 \ldots$. & 13 \\
\hline LATIHAN SOAL 2. & 34 \\
\hline LEMBAR KERJA $2 \ldots$ & 36 \\
\hline FTAR PUSTAKA & \\
\hline
\end{tabular}




\section{BAB I}

\section{PENDAHULUAN}

Masalah yang paling kursial dan sangat berpengaruh terhadap eksistensi kinerja lembaga keuangan perbankan adalah yang berkaitan dengan masalah kredit macet. Masalah kredit macet menjadi sangat penting dan menjadi skala prioritas dalam penanganannya karena basis kegiatan lembaga ini adalah penyaluran dana dalam bentuk kredit dan merupakan sumber pendapatan terbesar bagi dunia bisnis perbankan di samping sumber-sumber pendapatan terbesar bagi dunia bisnis perbankan disamping sumber-sumber pendapatan operasional lainnya.

Sumber dana fasilitas kredit yang diberikan sebagai kegiatan penyaluran dana bisnis perbankan dalam kegiatannya sebagai penghimpun dana masyarakat, karena menyangkut dana masyarakat maka setiap bentuk penyaluran dana oleh lembaga keuangan ini adalah berkaitan dengan kepentingan masyarakat. Oleh karena itu, penyaluran kredit oleh perbankan harus dilakukan secara hati-hati dengan proyeksi perhitungan yang mapan dan bertanggung jawab. Dalam kenyataan praktek kegiatan usaha perbankan, pihak perbankan telah berupaya melakukan kegiatan penyaluran kredit secara ketat dan hati-hati dengan masyarakat berbagai kriteria terhadap debitur (peminjam) dan memiliki prinsip-prinsip yang menjadi pedoman serta ketentuan dan kebijakan-kebijakan internal perbankan yang cukup komorehensif dan ketat namun tidak sedikit dijumpai dan terjadi kredit macet.

Prinsip $5 \mathrm{C}$ telah menjadi patokan dalam pemberian fasilitas kreedit yang disalurkan oleh perbankan akan tetapi tidak dapat menghindarkan satu bankpun dari persoalan terjadinya kredit macet. Dapat dikatakan bahwa tidak ada bank yang tidak mengalami adanya kredit macet. Kondisi perbankan ahur-ahir ini justru mengungkapkan seberapa besar kredit-kredit macet yang 
terjadi. Akibat kredit macet yang terakumulasi sebegitu besar dan tidak terselesaikan telah mengakibatkan tingkat kesehatan kondisi perbankan di Indonesia kinerjanya menjadi sangat buruk. Bahkan lebih jauh telah memberikan andil besar terjadinya keterpurukan ekonomi Nasional Negara sehingga terjadinya krisis ekonomi dan moneter yang berkepanjangan dan sangat tidak mudah untuk menganalisanya. 


\section{BAB II}

\section{PEMBAHASAN TEORI}

\section{KREDIT PERBANKAN}

Suyatno (2003:13) mengemukakan bahwa, pengertian kredit menurut Undang-Undang Nomor 14 tahun 1967 tentang Pokok-pokok Perbankan, yang dimaksud uang atau tagihan sesuai dengan kesepakatan pinjaman antara bank dengan debitur dengan ketentuan pihak peminjam wajib melunasi hutangnya setelah jangka waktu tertentu dengan jumlah bunga yang telah disepakati. Dari pengertian di atas dapatlah diambil penjelasan bahwa kredit mengandung pengertian adanya suatu kepercayaan dari seseorang atau badan yang diberikan kepada seseorang atau badan lainnya yaitu bahwa yang bersangkutan (debitur) pada masa yang akan datang akan memenuhi kewajiban yang telah diperjanjikan dan disepakati terlebih dahulu.

Tujuan utama pemberian kredit menurut Kasmir (2014:88) adalah sebagai berikut:

1. Mencari keuntungan Yaitu bertujuan untuk memeroleh hasil dari pemberian kredit yang disalurkan dalam bentuk bunga yang diterima oleh bank sebagai balas jasa dan biaya administrasi kredit yang dibebankan kepada debitur.

2. Membantu Usaha Nasabah Membantu usaha nasabah yang membutuhkan dana, sehingga pihak debitur dapat mengembangkan usahanya.

3. Membantu pemerintah Bagi pemerintah semakin banyak kredit yang disalurkan oleh perbankan, maka semakin baik, karena semakin banyak kredit yang disalurkan berarti terjadi peningkatan pembangunan di berbagai sector.

\section{PRINSIP-PRINSIP DALAM KREDIT PERBANKAN}


Peluncuran kredit oleh suatu bank mestilah dilakukan dengan berpegangan pada beberapa prinsip, yaitu sebagai berikut :

1. Prinsip kepercayaan. Sesuai dengan asal kata kredit yang berarti kepercayaan, maka setiap pemberian kredit sebenarnya mestilah selalu dibarengi oleh kepercayaan. Yakni kepercayaann dari kreditur akan bermanfaatnya kredit bagi debitur sekaligus kepercayaan oleh kreditur bahwa debitur dapat membayar kembali kreditnya. Tentunya untuk bisa memenuhi unsur kepercayaan ini oleh kreditur mestilah dilihat apakah calon debitur memenuhi berbagai kriteria yang biasanya diberlakukan terhadap pemberian suatu kredit. Karena itu timbul prinsip lain yang disebut prinsip kehati-hatian.

2. Prinsip kehati-hatian. Prinsip kehati-hatian ini adalah salah satu konkretisasi dari prinsip kepercayaan dalam suatu pemberian kredit.

\section{PRINSIP 5C}

1. Character (Kepribadian) Salah satu unsur yang mesti diperhatikan oleh bank sebelum memberikan kreditnya adalah penilaian atas karakter kepribadian/watak dari calon debiturnya. Karena watak yang jelek akan menimbulkan perilaku-perilaku yang jelek pula.

2. Capacity (kemampuan) Seorang calon debitur harus pula diketahui kemampuan bisnisnya, sehingga dapat diprediksi kemampuannya untuk melunasi hutangnya.

3. Capital (Modal) Permodalan dari suatu debitur juga merupakan hal yang penting harus diketahui oleh calon krediturnya. Karena permodalan dan kemampuan keuangan dari suatu debitur akan mempunyai korelasi langsung dengan tingkat kemampuan bayar kredit. Jadi masalah likuiditas dan solvabilitas dari suatu badan usaha menjadi penting artinya. 
4. Condition of Economy (Kondisi Ekonomi) Kondisi perekonomian secara mikro maupun makro merupakan faktor penting pula untuk dianalisis sebelum suatu kredit diberikan, terutama yang berhubungan langsung dengan bisnisnya pihak debitur.

5. Collateral (Agunan) Tidak diragukan lagi bahwa betapa pentingnya fungsi agunan dalam setiap pemberian kredit.

\section{KREDIT BERMASALAH}

Kredit bermasalah ialah kredit yang tidak lancar atau kredit dimana debiturnya tidak dapat memenuhi persyaratan yang diperjanjikan, misalnya persyaratan pembayaran bunga, pengambilan pokok pinjaman, peningkatan margin deposit, pengikatan dan peningkatan agunan, dan sebagainya." Penggolongan pembiayaan bermasalah menurut (sholahuddin, 2005: 25) :

1. Pembiayaan kurang lancar adalah terdapat tunggakan margin antara 3-6 bulan, jika pembiayaan belum jatuh tempo, Pembiayaan telah jatuh tempo dan belum dibayar, tetapi belum melampaui 3 bulan.

2. Pembiayaan yang diragukan Pembiayaan masih dapat diselamatkan dan jaminanya bernilai sekurang-kurangnya 75\% Pembiayaan tidak dapat diselamatkan, tetapi jaminannya bernilai sekurang-kurangnya $100 \%$ dari hutang.

3. Pembiayaan yang macet Memenuhi kriteria diragukan tetapi dalam jangka waktu 21 bulan sejak digolongkan diragukan belum ada pelunasan/usaha penyelamatan pembiayaan, Penyelesaian pembiayaan tersebut telah diserahkan kepada pengadilan negeri/ telah diajukan penggantian ganti rugi kepada perusahaan asuransi kredit. 
Menurut (Kasmir 2004:115) Dalam praktiknya kemacetan suatu kredit disebabkan 2 unsur sebagai berikut:

1. Dari pihak perbankan Dalam melakukan analisisnya, pihak analisis kurang teliti sehingga apa yang terjadi, tidak diprediksi sebelumnya atau mungkin salah dalam melakukan perhitungan.

2. Dari pihak nasabah kemacetan kredit dapat dilakukan akibat 2 hal yaitu: Adanya unsur kesengajaan. Dalam hal ini nasabah sengaja untuk tidak bermaksud membayar kewajibannya kepada bank sehingga kredit yang diberikan macet, Adanya unsur tidak sengaja. Artinya debitur mau membayar akan tetapi tidak mampu. Contohnya kredit yang dibiayai mengalami musibah seperti kebakaran, kebanjiran dan sebagainya sehingga kemampuan untuk membayar kredit tidak ada.

\section{KEBIJAKAN MENGATASI KREDIT MACET}

Beberapa Kebijakan dalam Mengatasi Kredit Macet, yaitu:

\section{Penjadwalan kembali (rescheduling)}

Cara ini dilakukan dengan menyesuaikan tenor pinjaman Anda agar bisa kembali mencicil pembayaran kredit. Pihak bank akan memperpanjang tenor pinjaman dari debitur yang mengalami kredit macet. Hal ini dilakukan agar angsuran yang harus dibayar bisa semakin ringan. Perpanjangan tenor juga disesuaikan dengan kemampuan pembayaran debitur. 


\section{Persyaratan kembali (restructuring)}

Cara kedua adalah dengan restructuring atau mengubah syarat-syarat peminjaman, yang mencakup perubahan jadwal pembayaran, jangka waktu, dan persyaratan lainnya. Persyaratan kembali ini bisa dilakukan dengan syarat tidak mengubah maksimal plafon kredit.

\section{Penataan kembali (reconditioning)}

Cara ketiga adalah dengan penataan kembali, yaitu upaya pihak bank mengubah kondisi kredit untuk meringankan tanggung jawab debitur yang terlibat kredit macet. Hal ini dilakukan dengan cara menambah fasilitas kredit, mengonversi tunggakan menjadi pokok kredit baru, hingga penjadwalan dan persyaratan kembali.

\section{Kombinasi}

Kombinasi, Merupakan kombinasi dari ketiga jenis yang diatas. Seorang nasabah bisa diselamatkan dengan kombinasi rescheduling dengan retructing.

\section{Penyitaan jaminan}

Penyitaan jamianan merupakan jalan terakhir apabila nasabah sudah benar-benar tidak punya etikad baik ataupun sudah tidak mampu lagi untuk membayar semua hutang-hutangnya 


\section{BAB III}

SOAL LATIHAN DAN LEMBAR KERJA

\section{SOAL LATIHAN 1}

\section{BKD "MAJU MAPAN"}

NERACA PER 1 DESEMBER 2017

\begin{tabular}{|l|l|l|l|l|l|}
\hline No & \multicolumn{1}{|c|}{ Perkiraan } & Jumlah (Rp.) & No & \multicolumn{1}{|c|}{ Perkiraan } & Jumlah (Rp) \\
\hline 1 & Kas & $120,000,000$ & 9 & Hutang pajak & $2,500,000$ \\
\hline 2 & Antar Bank Aktiva & $450,000,000$ & 10 & Tabungan & $400,000,000$ \\
\hline 3 & Perlengkapan & $20,000,000$ & 11 & Antar Bank Pasiva & $250,000,000$ \\
\hline 4 & Pinjaman Yang diberikan & $500,000,000$ & 12 & Modal & $460,000,000$ \\
\hline 6 & Porsekot Sewa Gedung & $15,000,000$ & 13 & Cad Kerugian Piutang & $2,500,000$ \\
\hline 7 & Aktiva Tetap & $15,000,000$ & & & \\
\hline 8 & Akum Peny Akt Tetap & $-5,000,000$ & & & $1,115,000,000$ \\
\hline & Jumlah & $1,115,000,000$ & & Jumlah & \\
\hline
\end{tabular}

Keterangan Neraca:

1. Antar Bank Aktiva terdiri dari:

Bank Mandiri Rp. 250,000,000; dan BNI Rp. 200,000,000

2. Pinjaman Yang Diberikan tediri dari:

Dani, Diki, Dini, Dinda dan Dena semua masing-masing Rp.100,000,000

3. Tabungan terdiri: Aisyah, Adam, Ani, Andi dan Andre masing-masing Rp. 80,000,000

4. Antar Bank Pasiva terdiri dari:

BRI Rp. 150,000,000 dan Bank Niaga Rp. 100,000,000 
5. Bunga angsuran dan pelunasan Pinjamanan Yang diberikan sebesar $2 \%$ dari nominal pimjaman

Contoh: Nominal Pinjaman Rp. 10,000,000. Tgl ttt dilunasi, maka besarnya pelunasan adalah Rp. 10,000,000. Bunga $2 \%$ dari Rp. 10,000,000= Rp. 200,000, Total Rp. 10,200,000. Jika mengangsur, nominal Pinjaman Rp. 10,000,000. Tgl ttt diangsur Rp 3,000,000 ditambah $2 \%$ dari Rp. 10,000,000 $=$ Rp. 200,000 maka total angsuran $=\mathrm{Rp}$ $3,200,000$

6. Bunga Tabungan $1 \%$ dan pajak atas bunga tersebut sebesar $10 \%$

7. Bunga $\mathrm{ABA} 1,5 \%$ per bulan dan biaya administrasi $10 \%$ dari bunga $\mathrm{ABA}$, sedangkan bunga $\mathrm{ABP} 1 \%$ dan potongan administrasi $10 \%$ dari bunga $\mathrm{ABP}$

Selama bulan Desember trjadi transaksi-transaksi sebagai berikut:

Tgl 2 : Aisyah menarik tabungan sebesar Rp. 25,000,000

Tgl 3 : Menerima pelunasan pinjaman dari Dani Solo

Tgl 4 : Adam menyetor tabungan sebesar Rp 10,000,000

Tgl 5 : Ditarik uang dari Bank Mandiri sebesar Rp. 100,000,000

Tgl 6 : Ani menarik tabungan sebesar $\operatorname{Rp~80,000,000~}$

Tgl 7 : Menerima setoran dari BRI Rp. 25,000,000

Tgl 7 : menerima angsuran pinjaman dari Diki Solo Rp. 20,000,000

Tgl 8 : Andi menarik tabungan sebesar Rp 75,000,000

Tgl 8 : Menerima angsuran pinjaman dari Dini Solo Rp. 30,000,000

Tgl 9 : Ditarik simpanan oleh Bank Niaga Rp. 50,000,000

Tgl 9 : Menerima pelunasan pinjman dari Dinda Solo 
Tgl 10 : Andre menarik tabungan sebesar Rp 40,000,000

Tgl 10 : Menerima angsuran pinjman dari Dena Solo Rp. 25,000,000

Tgl 11 : Disetor ke Bank Mandiri Rp. 50,000,000

Tgl 12 : Aisyah menarik tabungan sebesar Rp. 15,000,000

Tgl 13 : Ditarik uang dari BNI Rp, 50,000,000

Tgl 14 : Adam menyeyor tabungan sebesar Rp 15,000,000

Tgl 16: Ani menyetor tabungan sebesar Rp 40,000,000

Tgl 16 : Direalisasi pinjaman kepada Dani Solo Rp. 100,000,000 potongan adm dan Prop 1\%

Tgl 17 : Dibeli perlengkapan kantor Rp. 1,000,000 tunai

Tgl 18 : Andi menyetor tabungan sebesar Rp 35,000,000

Tgl 19 : Disetor ke BNI Rp. 50,000,000

Tgl 20 : Direaisasi pinjaman kepada Dinda Solo Rp. 75,000,000 potongan adm dan prop 1\%

Tgl 24 : Adam menarik tabungan sebesar Rp 65,000,000

Tgl 25 : Dibayar Gaji pegawai Rp. 5,000,000 
Pada akhir tahun, terdapat beberapa informasi sebagai berikut:

1. Cadangan Kerugian Piutang atau Pinjaman Yang Diberikan, dihitung dari saldo terakhir yang terdiri dari: Lancar sebesar 95\% dengan CKP 0,5\%; dan Diragukan sebesar $5 \%$ dengan CKP sebesar 5\%

2. Porsekot Sewa Gedung dibayar pada awal Desember untuk 15 bulan kedepan

3. Penyusutan Aktiva Tetap $10 \%$

4. Pajak tahun ini Rp. 1,000,000 dan belum dibayar

Maka kerjakan pada lembar yang tersedia:

1. Buku Kas Masuk, Buku Kas Keluar dan Nota Pengendalian Iternal (NPI)

2. Kartu Rekening Pinjaman Yang diberikan, Tabungan, ABA, ABP dan Daftar Saldonya

3. Buku Rekapitulasi akhir

4. Laporan Laba Rugi perusahaan

5. Nerca AKhir tahun.

(Sudarto, n.d.)

(Isanty, 2015) 
1. BUKU JURNAL

a. BUKU KAS MASUK

\begin{tabular}{|c|c|c|c|c|c|c|}
\hline \multirow{3}{*}{$\mathrm{Tg}$} & \multirow{3}{*}{ Keterangan } & \multirow{3}{*}{$\begin{array}{c}\text { Debet } \\
\text { Kas }\end{array}$} & \multicolumn{4}{|c|}{ Kredit } \\
\hline & & & \multirow{2}{*}{$\begin{array}{c}\text { Pinjm } \\
\text { Yg Diberikn }\end{array}$} & \multirow[b]{2}{*}{ Tabungan } & \multicolumn{2}{|c|}{ Serba serbi } \\
\hline & & & & & Perkiraan & Jumlah \\
\hline & & & & & & \\
\hline & & & & & & \\
\hline & & & & & & \\
\hline & & & & & & \\
\hline & & & & & & \\
\hline & & & & & & \\
\hline & & & & & & \\
\hline & & & & & & \\
\hline & & & & & & \\
\hline & & & & & & \\
\hline & & & & & & \\
\hline & & & & & & \\
\hline & & & & & & \\
\hline & & & & & & \\
\hline & & & & & & \\
\hline & & & & & & \\
\hline & & & & & & \\
\hline
\end{tabular}


b. BUKU KAS KELUAR

\begin{tabular}{|c|c|c|c|c|c|c|}
\hline \multirow{3}{*}{$\mathrm{Tg}$} & \multirow{3}{*}{ Keterangan } & \multicolumn{4}{|c|}{ Debet } & \multirow{2}{*}{$\begin{array}{c}\text { Kredit } \\
\text { Kas }\end{array}$} \\
\hline & & \multirow{2}{*}{$\begin{array}{l}\text { Pinjaman } \mathrm{Yg} \\
\text { Diberikan }\end{array}$} & \multirow{2}{*}{ Tabungan } & \multicolumn{2}{|c|}{ Serba serbi } & \\
\hline & & & & Perkiraan & $\begin{array}{l}\text { Jumlah } \\
\end{array}$ & \\
\hline & & & & & & \\
\hline & & & & & & \\
\hline & Dipindahkan & & & & & \\
\hline & Pindahan & & & & & \\
\hline & & & & & & \\
\hline & & & & & & \\
\hline & & & & & & \\
\hline & & & & & & \\
\hline & & & & & & \\
\hline & & & & & & \\
\hline & & & & & & \\
\hline & & & & & & \\
\hline & & & & & & \\
\hline & & & & & & \\
\hline & & & & & & \\
\hline & Jumlah & & & & & \\
\hline
\end{tabular}


c. NOTA PEMBUKUAN INTERNAL

\begin{tabular}{|l|l|l|l|}
\hline Tgl & Perkiraan & Debet & Kredit \\
\hline & & & \\
\hline & & & \\
\hline & & & \\
\hline & & & \\
\hline & & & \\
\hline & & & \\
\hline & & & \\
\hline & & & \\
\hline & & & \\
\hline & & & \\
\hline & & & \\
\hline & & & \\
\hline & & & \\
\hline & & & \\
\hline
\end{tabular}




\begin{tabular}{|r|r|r|r|}
\hline & & & \\
\hline & & & \\
\hline & & & \\
\hline & & & \\
\hline & dipindahkan & & \\
\hline & Pindahan & & \\
\hline & & & \\
\hline & & & \\
\hline & & & \\
\hline & & & \\
\hline & & & \\
\hline & & & \\
\hline & & & \\
\hline & & & \\
\hline & & & \\
\hline
\end{tabular}




\begin{tabular}{|r|r|r|r|}
\hline & & & \\
\hline & & & \\
\hline & & & \\
\hline & & & \\
\hline & & & \\
\hline & Jumlah & & \\
\hline & & & \\
\hline
\end{tabular}




\section{KARTU REKENING ABA}

Kartu Rekening ABA Bank Mandiri

\begin{tabular}{|c|c|c|c|c|c|}
\hline \multirow{2}{*}{$\mathrm{Tg}$} & \multirow{2}{*}{ Keterangan } & \multicolumn{2}{|c|}{ Mutasi } & \multicolumn{2}{|c|}{ Saldo } \\
\hline & & Debet & Kredit & Debet & Kredit \\
\hline & & & & & \\
\hline & & & & & \\
\hline & & & & & \\
\hline & & & & & \\
\hline & Jumlah & & & & \\
\hline
\end{tabular}

Kartu Rekening ABA BNI

\begin{tabular}{|c|c|c|c|c|c|}
\hline \multirow{2}{*}{ Tg } & \multirow{2}{*}{ Keterangan } & \multicolumn{2}{|c|}{ Mutasi } & \multicolumn{2}{|c|}{ Saldo } \\
\cline { 3 - 6 } & & Debet & Kredit & & \\
\hline & & & & & \\
\hline & & & & & \\
\hline & Jumlah & & & & \\
\hline
\end{tabular}




\section{KARTU REKENING PINJAMAN YANG DIBERIKAN}

Kartu Rekening Pinjaman Dani

\begin{tabular}{|c|l|c|c|c|c|}
\hline \multirow{2}{*}{ Tg } & \multirow{2}{*}{ Keterangan } & \multicolumn{2}{|c|}{ Mutasi } & \multicolumn{2}{c|}{ Saldo } \\
\cline { 3 - 6 } & & Debet & Kredit & & \\
\hline & & & & & \\
\hline & & & & & \\
\hline
\end{tabular}

Kartu Rekening Pinjaman Diki

\begin{tabular}{|c|c|c|c|c|c|}
\hline \multirow{2}{*}{$\mathrm{Tg}$} & \multirow{2}{*}{ Keterangan } & \multicolumn{2}{|c|}{ Mutasi } & \multicolumn{2}{|c|}{ Saldo } \\
\hline & & Debet & Kredit & Debet & Kredit \\
\hline & & & & & \\
\hline & & & & & \\
\hline & & & & & \\
\hline
\end{tabular}


Kartu Rekening Pinjaman Dini

\begin{tabular}{|c|l|l|l|l|l|}
\hline \multirow{2}{*}{ Tg } & \multirow{2}{*}{ Keterangan } & \multicolumn{2}{|c|}{ Mutasi } & \multicolumn{2}{|c|}{ Saldo } \\
\cline { 3 - 6 } & & Debet & Kredit & Debet & \\
\hline & & & & & \\
\hline & & & & & \\
\hline
\end{tabular}

Kata Rekening Pinjaman Dinda

\begin{tabular}{|c|c|c|c|c|c|}
\hline \multirow{2}{*}{$\mathrm{Tg}$} & \multirow{2}{*}{ Keterangan } & \multicolumn{2}{|c|}{ Mutasi } & \multicolumn{2}{|c|}{ Saldo } \\
\hline & & Debet & Kredit & Debet & Kredit \\
\hline & & & & & \\
\hline & & & & & \\
\hline & & & & & \\
\hline
\end{tabular}


Kartu Rekening Pinjaman Dena, Solo

\begin{tabular}{|c|c|c|c|c|c|}
\hline \multirow{2}{*}{$\mathrm{Tg}$} & \multirow{2}{*}{ Keterangan } & \multicolumn{2}{|c|}{ Mutasi } & \multicolumn{2}{|c|}{ Saldo } \\
\hline & & Debet & Kredit & Debet & Kredit \\
\hline & & & & & \\
\hline & & & & & \\
\hline & & & & & \\
\hline
\end{tabular}




\section{KARTU REKENING TABUNGAN}

Kartu Rekening Tabungan Aisyah Solo

\begin{tabular}{|c|c|c|c|c|c|}
\hline \multirow{2}{*}{$\mathrm{Tg}$} & \multirow{2}{*}{ Keterangan } & \multicolumn{2}{|c|}{ Mutasi } & \multicolumn{2}{|c|}{ Saldo } \\
\hline & & Debet & Kredit & Debet & Kredit \\
\hline & & & & & \\
\hline & & & & & \\
\hline & & & & & \\
\hline & & & & & \\
\hline & & & & & \\
\hline & & & & & \\
\hline
\end{tabular}


Kartu Rekening Tabungan Adam Solo

\begin{tabular}{|c|c|c|c|c|c|}
\hline \multirow{2}{*}{$\mathrm{Tg}$} & \multirow{2}{*}{ Keterangan } & \multicolumn{2}{|c|}{ Mutasi } & \multicolumn{2}{|c|}{ Saldo } \\
\hline & & Debet & Kredit & Debet & Kredit \\
\hline & & & & & \\
\hline & & & & & \\
\hline & & & & & \\
\hline & & & & & \\
\hline & & & & & \\
\hline & & & & & \\
\hline
\end{tabular}


Kartu Rekening Tabungan Ani Solo

\begin{tabular}{|c|c|c|c|c|c|}
\hline \multirow{2}{*}{$\mathrm{Tg}$} & \multirow{2}{*}{ Keterangan } & \multicolumn{2}{|c|}{ Mutasi } & \multicolumn{2}{|c|}{ Saldo } \\
\hline & & Debet & Kredit & Debet & Kredit \\
\hline & & & & & \\
\hline & & & & & \\
\hline & & & & & \\
\hline & & & & & \\
\hline & & & & & \\
\hline & & & & & \\
\hline
\end{tabular}


Kartu Rekening Tabungan Andi Solo

\begin{tabular}{|c|c|c|c|c|c|}
\hline \multirow{2}{*}{$\mathrm{Tg}$} & \multirow{2}{*}{ Keterangan } & \multicolumn{2}{|c|}{ Mutasi } & \multicolumn{2}{|c|}{ Saldo } \\
\hline & & Debet & Kredit & Debet & Kredit \\
\hline & & & & & \\
\hline & & & & & \\
\hline & & & & & \\
\hline & & & & & \\
\hline & & & & & \\
\hline & & & & & \\
\hline
\end{tabular}


Kartu Rekening Tabungan Andre Solo

\begin{tabular}{|c|c|c|c|c|c|}
\hline \multirow{2}{*}{$\mathrm{Tg}$} & \multirow{2}{*}{ Keterangan } & \multicolumn{2}{|c|}{ Mutasi } & \multicolumn{2}{|c|}{ Saldo } \\
\hline & & Debet & Kredit & Debet & Kredit \\
\hline & & & & & \\
\hline & & & & & \\
\hline & & & & & \\
\hline & & & & & \\
\hline & & & & & \\
\hline & & & & & \\
\hline
\end{tabular}




\section{KARTU REKENING ABP}

Kartu Rekening ABP BRI

\begin{tabular}{|c|c|c|c|c|c|}
\hline \multirow{2}{*}{$\mathrm{Tg}$} & \multirow{2}{*}{ Keterangan } & \multicolumn{2}{|c|}{ Mutasi } & \multicolumn{2}{|c|}{ Saldo } \\
\hline & & Debet & Kredit & Debet & Kredit \\
\hline & & & & & \\
\hline & & & & & \\
\hline & & & & & \\
\hline & & & & & \\
\hline
\end{tabular}

Kartu Rekening ABP Bank Niaga

\begin{tabular}{|c|c|c|c|c|c|}
\hline $\mathrm{Tg}$ & Keterangan & \multicolumn{2}{|c|}{ Mutasi } & \multicolumn{2}{|c|}{ Saldo } \\
\hline & & & & & \\
\hline & & & & & \\
\hline
\end{tabular}


DAFTAR SALDO: ABA, PINJAMAN, TABUNGAN, ABP

\begin{tabular}{|l|l|l|l|l|l|}
\hline No & Keterangan & ABA & Pinjaman & Tabungan & ABP \\
\hline & & & & & \\
\hline & & & & & \\
\hline & & & & & \\
\hline & & & & & \\
\hline & & & & & \\
\hline & & & & & \\
\hline & & & & & \\
\hline & & & & & \\
\hline & & & & & \\
\hline & & & & & \\
\hline & & & & & \\
\hline & & & & & \\
\hline & & & & \\
\hline Jumlah & & & & \\
\hline
\end{tabular}


6. BUKU REKAPITULASI AKHIR

\begin{tabular}{|l|l|l|l|}
\hline Tg & Perkiran & Debet & Kredit \\
\hline & & & \\
\hline & & & \\
\hline & & & \\
\hline & & & \\
\hline & & & \\
\hline & & & \\
\hline & & & \\
\hline & & & \\
\hline & & & \\
\hline & & & \\
\hline & & & \\
\hline & & & \\
\hline & & & \\
\hline & & & \\
\hline & & & \\
\hline
\end{tabular}




\begin{tabular}{|r|r|r|r|}
\hline & & & \\
\hline & Dipinahkan & & \\
\hline & pindahan & & \\
\hline & & & \\
\hline & & & \\
\hline & & & \\
\hline & & & \\
\hline & & & \\
\hline & & & \\
\hline & & & \\
\hline & & & \\
\hline & Jumlah & & \\
\hline & & & \\
\hline & & & \\
\hline & & & \\
\hline
\end{tabular}




\section{LAPORAN RUGI LABA}

\begin{tabular}{|r|l|l|l|}
\hline \multicolumn{1}{|c|}{ No } & \multicolumn{1}{|c|}{ Perkiraan } & Jumlah 1 & Jumlah 2 \\
\hline A & PENDAPATAN: & & \\
\hline 1 & & & \\
\hline 2 & & & \\
\hline 3 & & & \\
\hline 4 & & & \\
\hline B & BIAYA-BIAYA: & & \\
\hline 1 & & & \\
\hline 2 & & & \\
\hline 3 & & & \\
\hline 4 & & & \\
\hline 5 & & & \\
\hline 6 & & & \\
\hline 7 & & & \\
\hline
\end{tabular}




\begin{tabular}{|r|l|l|l|}
\hline 8 & & & \\
\hline & \multicolumn{1}{|c|}{ Jumlah biaya } & & \\
\hline & Laba sebelum pajak & & \\
\hline & Pajak & & \\
\hline & Laba tahun berjalan setelah pajak & & \\
\hline & & & \\
\hline
\end{tabular}

8, NERACA 31 DESEMBER 2000

\begin{tabular}{|l|l|l|l|l|l|}
\hline No & Perkiraan & Jumlah & No & Perkiraan & Jumlah \\
\hline & & & & & \\
\hline & & & & & \\
\hline & & & & & \\
\hline & & & & & \\
\hline & & & & & \\
\hline & & & & & \\
\hline & & & & & \\
\hline
\end{tabular}





\section{SOAL LATIHAN 2}

Tanggal 12 September 2017. BKD “MAJU MAKMUR” mengajukan permohonan kredit Rp. 150.000.000. Setelah diadakan rapat komite kredit, tanggal 15 September diputuskan sbb:

Nama Debitur : BKD "MAJU MAKMUR”

Maksimal Kredit : Rp. 100.000.000

Keperluan : Membeli mobil Suzuki 900 cc (1 buah)

Jangka Waktu : 3 bulan

Bunga : $11 \%$ pertahun

Pembayaran Bunga : tiap bulan dibebankan ke rekening nasabah

Bentuk Pinjaman : Pinjaman R/K

Pencairan Pinjaman : menarik cek yang nilainya tidak lebih dari plafond kredit, kecuali dalam perjanjian diperbolehkan overdraft.

Biaya Provisi : $0.5 \%$ dari plafond kredit

Biaya Administrasi : Rp. 500.000

Asuransi : ditutup pada PT. Asuransi Indonesia

Jaminan :

- Jaminan Pokok = berupa benda yang dibiayai kredit tsb

- Jaminan Tambahan $=\quad$ Kendaraan Bermotor 40.000.000

Deposito Berjangka $\quad 30.000 .000$

Mesin $\quad 25.000 .000$

Emas $\quad 35.000 .000$ 
1. Pada 16 September 2017. BKD "MAJU MAKMUR" mengikat benda jaminan dan mengisi Persetujuan Membuka Kredit (PMK)

2. Pada 17 Sepetember 2017. BKD "MAJU MAKMUR" membayar biaya pembukuan kredit secara pemindah bukuan

Tahap Realisasi :

1. Tanggal 18 September 2017. BKD "MAJU MAKMUR" menarik cek pinjaman Rp. 100.000.000 dan dana tersebut dimasukkan ke dalam rekening gironya

2. Pencadangan bunga kredit dilakukan setiap akhir bulan

3. Tanggal 18 Desember 2017. BKD "MAJU MAKMUR" melunasi kredit dan bunganya dengan membayar tunai

Buatlah proses kredit BKD "MAJU MAKMUR" mulai dari pengikatan jaminan sampai pelunasan Kredit!

Maka kerjakan pada lembar yang tersedia:

1. Tahap pengikatan jaminan

2. Tahap realisasi kredit

3. Pengawasan kredit

4. Pelunasank redit 


\section{TAHAP PENGIKATAN JAMINAN}

Tanggal 16 September 2017. Ditandatangani PMK dan mengikat benda jaminan secara notaris.

Benda Bergerak :

- Kendaraan bermotor dan mesin

FEO

- Deposito Berjangka

Cessi

- Emas

Gadai

Tanggal 17 September mambayar biaya-biaya

- Provisi $0.5 \% \times 100.000 .000=$

- Biaya Admin

$=$

Jurnal Pencatatannya :

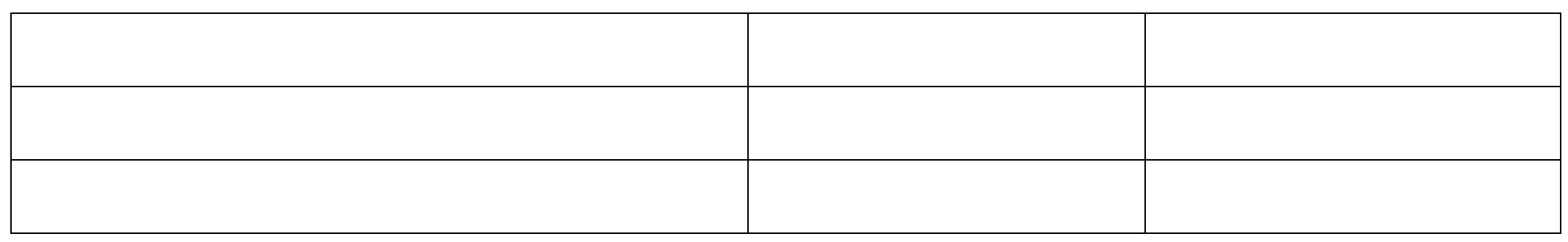




\section{TAHAP REALISASI KREDIT}

Tanggal 18 September 2017. BKD “MAJU MAKMUR" menarik pinjaman

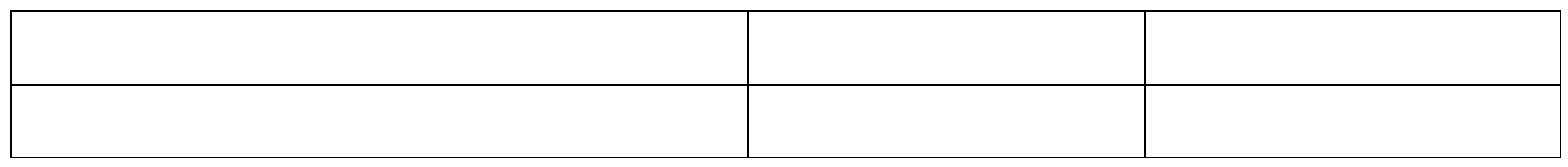

3. PENGAWASAN KREDIT

- $\quad$ Mengitung Pencadangan Bunga Pertama (18 Sept - 30 Sept $)=13$ Hari

\begin{tabular}{|l|l|l|}
\hline & & \\
\hline & & \\
\hline
\end{tabular}


- $\quad$ Menghitung Pembayaran Bunga Kredit (1 Okt -18 Okt $)=17$ hari

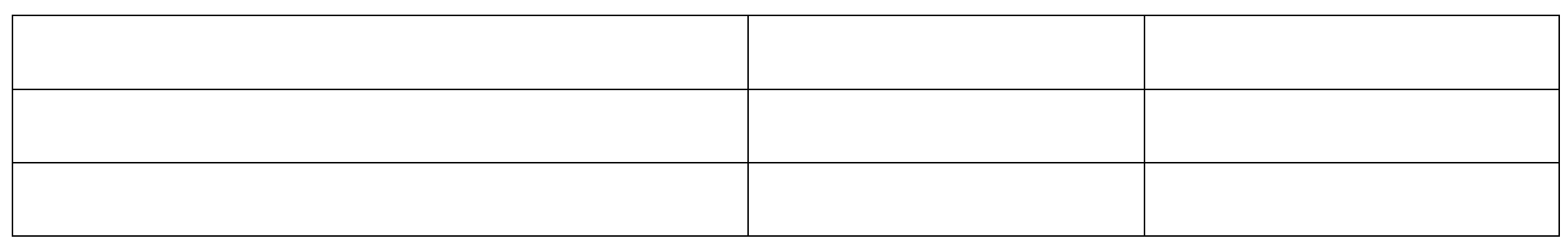

- $\quad$ Mengitung Pencadangan Bunga Kedua (18 Okt - 30 Okt $)=13$ Hari

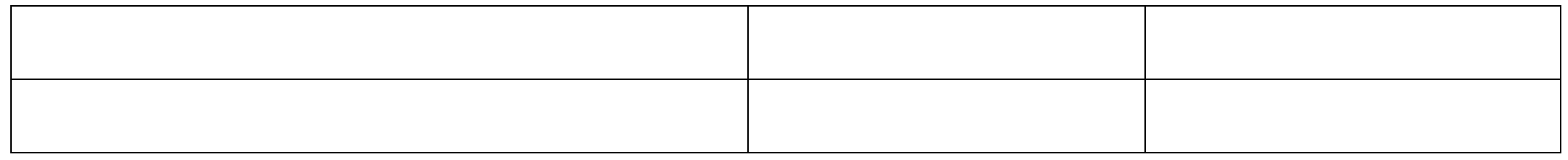


- $\quad$ Menghitung Pembayaran Bunga Kredit (1 Nov - 18 Nov $)=17$ hari

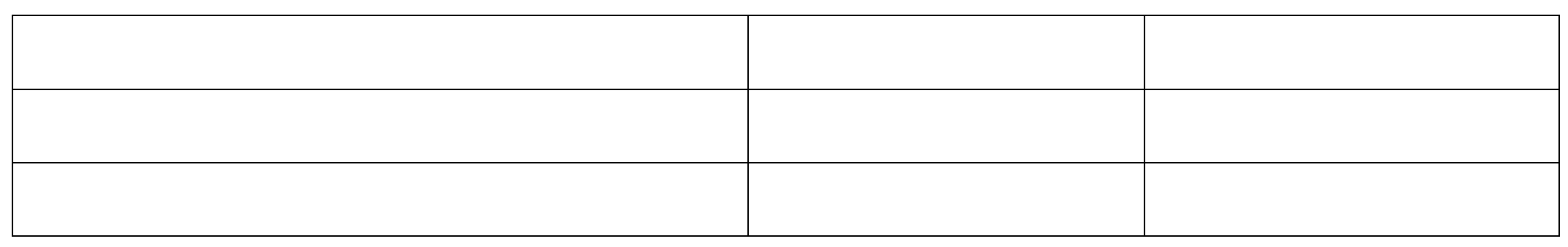

- $\quad$ Mengitung Pencadangan Bunga Ketiga (18 Nov - 30 Nov $)=13$ Hari

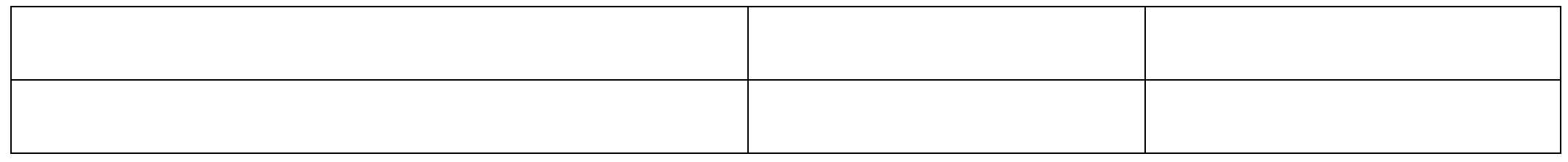


4. PELUNASAN KREDIT

(1 Desember -18 Desember $)=18$ Hari

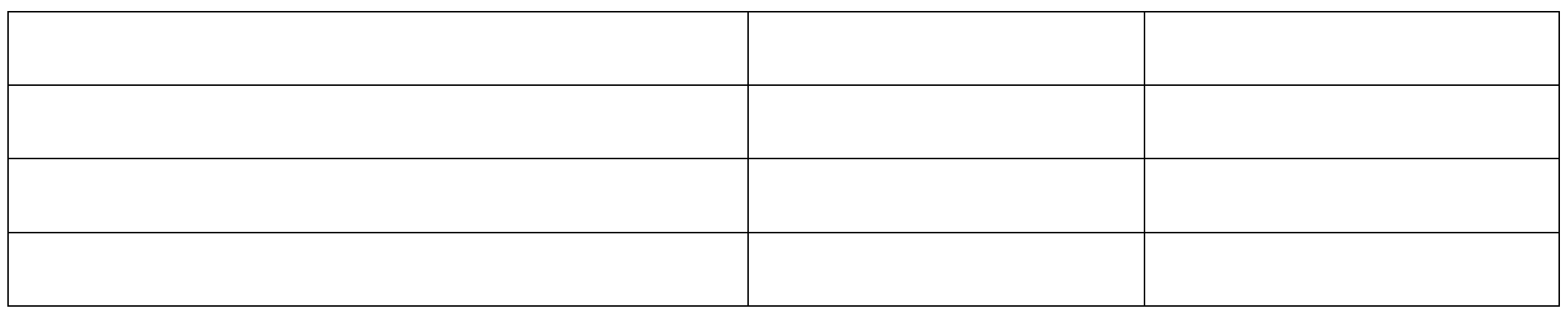




\section{DAFTAR PUSTAKA}

Isanty, M. (2015). Contoh Soal Kredit (Akuntansi Perbankan).

Http://Therealmeity.Blogspot.Com. http://therealmeity.blogspot.com/2015/12/contoh-soalkredit-akuntansi-perbankan.html

Sudarto, D. (n.d.). FINAL SEMESTER EXAM OF UNEVEN SEMESTER. http://pendakuntansi.ums.ac.id/wp-content/uploads/sites/78/2018/05/Soal-Akuntansi-Perbankan.docx 
hasil check plagiasinya silakan di upload

hasil check plagiasinya silakan di upload

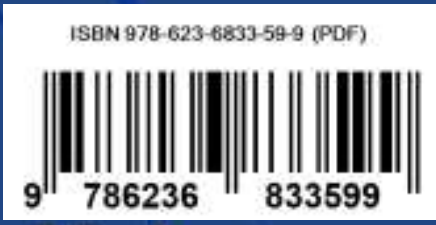

Universitas Muhammadiyah Sidoarjo

2021 